\title{
Canada-Renewable Energy: Implications for WTO Law on Green and Not-So-Green Subsidies
}

\author{
STEVE CHARNOVITZ* \\ George Washington University Law School \\ CAROLYN FISCHER ** \\ Resources for the Future (RFF) and Fondazione Eni Enrico Mattei (FEEM)
}

\begin{abstract}
In the first dispute on renewable energy to come to WTO dispute settlement, the domestic content requirement of Ontario's feed-in tariff was challenged as a discriminatory investment-related measure and as a prohibited import substitution subsidy. The Panel and Appellate Body agreed that Canada was violating the GATT and the TRIMS Agreement. But the SCM Article 3 claim by Japan and the European Union remains unadjudicated, because neither tribunal made a finding that the price guaranteed for electricity from renewable sources constitutes a 'benefit' pursuant to the SCM Agreement. Although the Appellate Body provides useful guidance to future Panels on how the existence of a benefit could be calculated, the most noteworthy aspect of the new jurisprudence is the Appellate Body's reasoning that delineating the proper market for 'benefit' analysis entails respect for the policy choices made by a government. Thus, in this dispute, the proper market is electricity produced only from wind and solar energy.
\end{abstract}

\section{Introduction}

The Canada-Renewable Energy/Feed-In Tariff case, ${ }^{1}$ adopted by the Dispute Settlement Body (DSB) in 2013, addresses the compatibility of renewable energy policy measures with World Trade Organization (WTO) obligations, in particular those containing local content requirements. The complainants, the European

\footnotetext{
* Email: scharnovitz@law.gwu.edu.

**Email: Fischer@rff.org.

The authors thank Luca Rubini for his helpful commentary at the authors' conference in June 2014. Fischer gratefully acknowledges the support of the European Community's Marie Curie International Incoming Fellowship, 'STRATECHPOL - Strategic Clean Technology Policies for Climate Change', financed under the EC Grant Agreement PIIF-GA-2013-623783.

1 Appellate Body Report, Canada - Certain Measures Affecting the Renewable Energy Generation Sector/Canada - Measures Relating to the Feed-In Tariff Program, WT/DS412/AB/R/WT/DS426/AB/R, adopted 24 May 2013.
} 
Union (EU) and Japan, easily won their case against Canada in that the Panel and the Appellate Body found violations of the non-discrimination disciplines laid out in the General Agreement on Tariffs and Trade (GATT) and the Agreement on Trade-Related Investment Measures (TRIMS). By contrast, the Appellate Body held that it was unable to complete its legal analysis regarding the challenge to Canada's discriminatory subsidies pursuant to the Agreement on Subsidies and Countervailing Measures (SCM). This anticlimactic denouement fogs up when government aid will be determined to be a 'benefit' under WTO subsidy law (Whitsitt, 2013). Although this case adds significantly to WTO jurisprudence on energy, environment, and the supervision of subsidies, new disputes over renewable energy issues will almost surely continue to occur (Flood, 2014).

Even though many key questions were left on the table (Shadikhodjaev, 2013), the Canada case advances WTO case law in several respects. First, the Appellate Body put an important gloss on the applicable exception (or carve-out) for government procurement in GATT Article III:8(a)-namely, that since both the obligations in Article III and the derogation in III:8(a) refer to discriminatory treatment of products, the same discriminatory treatment must exist with both in order to use the exception. Second, the Appellate Body explained that a measure could fit into more than one category of financial contributions in SCM Article 1.1(a)(1), which lays out the definition of a subsidy. Third, the Appellate Body explained that although the existence of benefit in SCM Articles 1.1(b) (whether a benefit is conferred) and 14 (the calculation thereof) is based on a comparison within a market, the market analysis must take into account governmental decisions regarding the appropriate mix of energy sources.

Although it may have been politically convenient for the WTO to avoid a judicial decision as to whether a lucrative feed-in tariff constitutes a subsidy under the WTO agreement, the Appellate Body decision unfortunately generates new instabilities and uncertainties for the WTO. According to the Appellate Body in Canada-Renewable Energy, 'Where a government creates a market, it cannot be said that the government intervention distorts the market, as there would not be a market if the government had not created it.' ${ }^{2}$ This axiom was then used by the Appellate Body to complicate the determination of whether a government purchase constitutes a benefit to the recipient in instances where the government claims that it is creating a new market. In future cases, this line of reasoning could be used by defendant governments to deny that their financial contributions to companies constitute a benefit under SCM rules.

This paper discusses Canada-Renewable Energy from both legal and economic perspectives. Section 2 summarizes the Canadian program being challenged and provides a brief overview of the WTO decision. Section 3 addresses the economics of renewable energy production and consumption. Section 4 analyzes some key 
holdings of the Panel and Appellate Body. Section 5 discusses some implications of the case for the trading system.

\section{Summary and overview of the case}

Although the official defendant in this case is Canada, the scofflaw is the government of the province of Ontario. That subnational government enacted a law in 2009 to incentivize the production of electricity from wind or solar generators that included a scheme to source a minimum level of the component parts and services from producers within Ontario. ${ }^{3}$ The WTO Panel called Ontario's electricity system a partially liberalized hybrid system whereby both public and private entities engage in generation, transmission, and distribution.

The Ontario government's involvement in the province's electricity market has been extensive. The government-owned Ontario Power Generation is the major supplier of electricity generation. The sub-state-owned enterprise Hydro One is the largest distribution utility in the province and almost completely owns the high-voltage transmission system. The grid is managed by the so-called Independent Electricity System Operator, another agency of Ontario's government. The legacy of regulatory interventions include longtime public ownership, ${ }^{4}$ longtime electricity price freeze, ${ }^{5}$ strict regulatory management by the governmental Ontario Power Authority, and a decision taken in 2007 to phase out all coalfired generation in the province by 2014. Note that in 2010, Ontario's installed capacity shares by source, in rank order from highest to lowest, were nuclear, hydropower, gas and oil, coal, and wind; other technologies had minute shares. ${ }^{6}$

Seeking to replace the capacity being lost by the coal phase-out with cleaner options, the Ontario government sought to incentivize greater production of wind and solar energy, ${ }^{7}$ choosing the widely used instrument of a feed-in tariff (FIT). A FIT is a long-term contract by a government agency to secure wholesale electricity at a set price that reflects a rate of return attractive to investors and developers. The incentive occurs because the price in the contract is generally above the

3 The record does not address whether Ontario's buy-provincial program violates Canadian federal law. A similar domestic program could be inconsistent with the internal laws of the EU, Japan, and the United States.

4 Indeed, according to the Panel Report, Ontario had the world's first publicly owned electrical utility.

5 The Panel explained that governments may mandate stable electricity prices with the predictable outcome of underinvestment in new electricity generation. Panel Report, Canada-Renewable Energy/ Canada-Feed-In Tariff Program, para. 7.284.

6 Appellate Body Report, Canada-Renewable Energy/Canada-Feed-in Tariff Program, para. 4.10 Table 2 .

7 The case mainly discusses electricity produced from wind and solar, but the FIT program also covers renewable biomass, biogas, landfill gas, and hydropower. Only wind and solar are subject to the domestic content requirements, however. 
wholesale price of power in the region (otherwise, there would be no incentive). Ontario's FIT contracts are 20 to 40 years.

Ontario had early success with renewable energy procurement, both through competitive bidding and the Renewable Energy Standard Offer Program (RESOP), a type of FIT program that began in 2006 for small-scale $(<10 \mathrm{MW}$ ) sources and reached its ten-year target of 1,000 $\mathrm{MW}$ in just over one year (Auditor General of Ontario, 2011). With the Green Energy and Green Economy Act of 2009, the RESOP was replaced with a new FIT program that was wider in scope, required made-in-Ontario components, and provided renewable energy generators with significantly more attractive contract prices, adding about $\$ 4.4$ billion in costs over the 20-year contract terms as compared with the previous terms (Auditor General of Ontario, 2011). Rapid oversubscription to the new contracts, for which caps were not set, has led to Ontario exporting power at a loss. ${ }^{8}$

Ontario's goals were not only to increase the role of wind and solar in the supplymix of electricity, but also to 'enable new green industries' and to provide incentives for investment in the manufacturing of renewable energy technology. Ontario linked eligibility for its generous FIT to a local content requirement (LCR), thus creating a second instrument to promote green industries. The combined policies help Ontario successfully negotiate an agreement with a Korean consortium that was estimated to bring $\$ 7$ billion of renewable generation investment, as well as 16,000 green energy jobs, to Ontario (Ministry of Energy, 2010).

The LCR defines 'content' in terms of the total project costs, and designated activities range from manufacturing certain components in Ontario to retaining labor and consulting services provided by Ontario residents. Specifically, the applicable regulations require that by 2012 , the minimum required domestic content be $50 \%$ for large wind installations and $60 \%$ for solar photovoltaic (PV). 9 The Panel found that the requirements were sufficiently high such that they could not be met absent some Ontario-sourced manufactured goods. ${ }^{10}$

The complaining governments did not challenge the FIT incentives directly as a violation of SCM Article 5 (Actionable Subsidies). Rather, the lawsuit in the WTO was premised on attacking the discrimination entailed in the minimum required domestic content level. To this end, three WTO provisions were invoked. First, there was a claim that the measures were inconsistent with TRIMS Article 2.111

8 The Auditor General of Ontario (2011) estimates that from 2005 to the audit's end in 2011, Ontario received $\$ 1.8$ billion less for its electricity exports than what it actually cost ratepayers.

9 Panel Report, Canada-Renewable Energy /Canada-Feed-In Tariff Program, para. 7.158 (Table 1).

10 Ibid., para.7.161.

11 TRIMS Article 2 (National Treatment and Quantitative Restrictions) states:

1. Without prejudice to other rights and obligations under GATT 1994, no Member shall apply any TRIM that is inconsistent with the provisions of Article III or Article XI of GATT 1994.

2. An illustrative list of TRIMs that are inconsistent with the obligation of national treatment provided for in paragraph 4 of Article III of GATT 1994 and the obligation of general elimination of 
by virtue of being inconsistent with GATT Article III:4, alleging a violation of national treatment. Second, there was a stand-alone claim under GATT Article III:4. ${ }^{12}$ Third, there was a claim of violation of SCM Articles 3.1(b) and 3.2, which forbid subsidies contingent on the use of domestic over imported goods. Importantly, this third claim was premised on being able to prove that the FIT incentives were subsidies under the SCM Agreement.

As noted above, Canada was adjudged to have violated WTO rules. Specifically, the Appellate Body upheld the Panel in finding that the local content provision violated GATT Article III:4 and therefore was ipso facto a violation of TRIMS Article 2.1. (Having found the Article III:4 violation in this fashion, the Appellate Body upheld the Panel's use of judicial economy in failing to address the GATT Article III:4 stand-alone claim.) Canada, however, did not lose on the SCM import substitution claim, because neither the Appellate Body nor the Panel determined that the FIT contracts constituted a subsidy under the SCM Agreement.

The issue of the existence of the subsidy is the most important part of the case, both from an environmental perspective and in terms of the development of subsidy law. Each of the two prerequisites (i.e., a financial contribution and a benefit) in the WTO definition of a subsidy was contested by the parties. Although both the Panel and Appellate Body found the FIT contracts to be a financial contribution, neither the Panel nor the Appellate Body was able to issue an affirmative finding that there was a benefit to the recipient.

The litigation may not yet be over, as Canadian compliance is still under way. The Appellate Body report was circulated on 6 May 2013 and adopted on 24 May 2013. On 5 June 2014, Canada informed the DSB that the government of Ontario had complied with the DSB recommendations and rulings by (1) no longer subjecting large renewable electricity procurements to domestic requirements and (2) significantly lowering the domestic content requirements for small and microFIT procurement of wind and solar electricity under the FIT Program. ${ }^{13}$ Nevertheless, as of mid-August 2014, the Ontario Power Authority website states that microFIT contracts continue to require domestic content. Whether either of the plaintiffs will challenge Canada's questionable assertion of compliance remains to be seen.

\section{The economics of electricity and renewable energy policies}

Electricity is not your average widget. With large networked infrastructure investments required, electricity markets are naturally imperfectly competitive, highly

quantitative restrictions provided for in paragraph 1 of Article XI of GATT 1994 is contained in the Annex to this Agreement.

12 GATT Article III:4 requires that imported products be treated no less favorably than like products of domestic origin.

13 Communication from Canada to the DSB, WT/DS412/19, DS/426/19, 6 June 2014. 
regulated, and sparsely traded internationally. Although consumers cannot distinguish among units of electricity $(\mathrm{kWh})$ once they are delivered to the grid, they do demand electricity supplies that are not just the least costly, but also secure, reliable, and even clean. And generation technologies have vastly different qualities. Some are considered as 'baseload' (that is, on nearly all the time); some can be ramped up and used for peaking; and some, like renewables, are intermittent. Technologies also vary in the composition of their costs (capital investments versus operation and input costs) and their environmental and health consequences (emissions, hazardous waste, siting, risks). For these reasons, electricity markets have always deployed multiple generation technologies, and governments have long intervened in influencing the generation portfolio to achieve broader goals of a diverse, secure, and reliable electricity system that can adapt to energy input price fluctuations and, more recently, the costs of environmental damages.

Ontario is not unique in taking aggressive measures to deploy renewable energy. Governments around the world have implemented various incentive-based mechanisms to accelerate renewable energy deployment. These measures range from direct subsidies or tax incentives to market-share mandates implemented with tradable credits to competitive bidding, and the use of multiple incentive mechanisms is commonplace. However, worldwide, the single most popular support program is the feed-in tariff (FIT). According to the International Energy Agency (IEA), more than 50 countries have FITs at some level of jurisdiction, including most of the governmental complainants in this case. ${ }^{14}$

Ontario is also not unique in imposing a local content requirement on a FIT. Several other governments do so as well (OECD, 2011: paras. 53-55). There are countries, too, that link other forms of renewable energy assistance to domestic content provisions. For example, in the United States, the states of Delaware, Minnesota, and Massachusetts use such local content requirements (WTO, 2014).

Many renewable energy measures can be construed, from an economic perspective, as subsidies for investment in new renewable energy capacity, implemented through generation subsidies. This nuance is important, as once installed, renewable energy generally has negligible variable costs and will always be dispatched if available (assuming the grid can absorb the supply). Thus, generation subsidies do not tend to encourage more power generation from existing renewable capacity; this fact stands in contrast to fossil fuel subsidies, which can encourage greater generation and dispatch, as well as capacity investment in non-renewable sources. The most explicit example of a renewable energy investment subsidy has been the US Federal Production Tax Credit (PTC), giving a 2.3-cent-perkilowatt-hour $(\mathrm{kWh})$ incentive for the first ten years of a renewable energy facility's

14 All complainants promote renewable energy with some measures. Most EU countries, China, the United States, Australia, Chinese Taipei, India, and Turkey use FITs; Korea recently replaced FIT programs with a national renewable portfolio standard. Japan has also used feed-in tariffs, at least since 2012. 
operation. ${ }^{15}$ Renewable portfolio standards (RPSs), on the other hand, offer implicit subsidies to renewable energy sellers in the form of green certificate values, financed by an implicit tax on generation, via the mandate to buy a certain proportion of renewable energy. ${ }^{16}$

FITs target future investments by offering new renewable energy installations long-term contracts that guarantee an elevated price (or price premium) for sales to the electricity grid. Electricity suppliers are required to buy generation from renewable sources at this price, and these extra costs are either compensated by governments (and thus borne by taxpayers) or, more often, passed on to consumers in the form of higher electricity costs (Sharp, 2013). The idea is to set prices high enough to provide sufficient incentive for investment, and the fact that prices are stable enhances the attractiveness of investment by eliminating price uncertainty. FITs have for the most part been viewed as successful in terms of deployment; by some estimates, they are responsible for approximately $75 \%$ of global solar photovoltaic (PV) and $45 \%$ of global wind capacity (Couture et al., 2010).

\subsection{Different treatment, different markets}

Renewable energy policies do not view all electricity generation as the same (or 'like'), by definition. FIT contracts usually differentiate among suppliers across several different dimensions. First, they often differentiate among renewable sources, offering higher prices for more expensive 'advanced' technologies (like solar photovoltaics), smaller-scale installations, or national energy priorities. By price-discriminating, FITs can ensure that technologies that are currently less competitive can be deployed, while avoiding paying excessively for technologies (like onshore wind) that are nearly competitive with conventional generation sources. Similarly, FITs also differentiate over time and vintages; they apply only to new capacity investment and offer early takers higher prices than later entrants, the idea being that the costs of these evolving technologies should fall over time. A policy challenge is always determining the appropriate level of compensation by technology: set the price too low and renewable energy targets will not be met; set the price too high and capacity investment will boom while funding sources may go bust. Germany and Spain (and then Ontario) learned this latter lesson the hard way, as generous terms spawned unexpectedly rapid oversubscription, leading to subsequent cuts in the terms but a legacy of large burdens for consumers and taxpayers. ${ }^{17}$

15 The effectiveness of the PTC incentive has been hampered by policy uncertainty, as it has frequently been allowed to expire before being renewed again.

16 Eligibility for selling green certificates is less likely to expire; most programs simply set an earliest year of construction for what defines a 'new renewable' source.

17 See, for example, http://www.economist.com/news/business/21582018-sustainable-energy-meetsunsustainable-costs-cost-del-sol. 
The other important dimension of differentiation is space: eligibility criteria for renewable incentives are frequently used to control the location of the beneficiaries. FIT contracts are generally restricted to installations physically located within the regulating jurisdiction; thus, imported electricity does not benefit from the incentives. Similarly, many RPSs require the renewable generation to occur within the local jurisdiction; others allow renewable energy credits (RECs) to be purchased from another state or region, even without grid connectivity, but rarely, if ever, are foreign RECs eligible. One exception is the state of Vermont, which allows imported electricity from large-scale hydropower sources in Quebec to count toward compliance with its RPS. Thus, the analogous option exists to eliminate discrimination by offering FIT contracts to any qualifying renewable source that feeds into the local grid, this being the main criterion to ensure that the incentivized renewable capacity is more likely to displace local emissions and feed local consumers. However, this issue was not the source of contention in the case at hand.

The controversy was that, in addition to these common provisions, Ontario also included an LCR that required a minimum share of project costs to be from Ontario goods and labor. In practice, the Ontario FIT is a blend of a marketbased instrument and a government procurement program. The Ontario Power Authority is given capacity procurement targets, with set-asides for aboriginal and community groups. An application process determines eligibility and ranks projects according to quality, thereby deciding which are awarded the FIT contract. From an economic perspective, implementation through procurement is incidental, as the same outcome could be implemented via regulations and market-based instruments in a deregulated, competitive electricity market.

In considering the economic impacts of such policies, it is useful to distinguish between the electricity market (generators) and the market for renewable technology components (manufacturers).

In general, renewable energy inducements like FITs convey a direct benefit to generators of renewable energy, to varying extents. The indirect consequence of expanding renewable generation is to drive down wholesale prices, which harms owners of existing non-renewable capacity and generally makes new fossil installations less competitive (although demand for capacity that can balance the intermittency of renewables may increase). Electricity consumers may win or lose, depending on how the subsidy is funded, the ambition level of the program, and the response of other market-based instruments like emissions trading (Fischer, 2010; Lecuyer and Fischer, 2014). Furthermore, it can be argued (from an economic perspective) that these subsidies are correcting for other distortions - implicit subsidies enjoyed by non-renewable energy producers when emissions pricing is below the social cost, explicit fossil fuel subsidies, or capital or innovation market failures relevant for newer technologies.

Even if one makes a case that FITs disadvantage certain generators in electricity markets, the fact is that the physical limitations of electricity distribution systems typically limit the international trade impacts. For example, the United States 
was the only party to the complaint (and a third-party at that) with electricity trade with Canada, and its total electricity trade (nearly all with Canada and mostly imports) represented less than $2 \%$ of electricity consumption in 2012 (EIA, 2014). By contrast, renewable technology products are traded intensively. As of 2012, the top manufacturers of wind turbines are from Germany, China, the United States, Denmark, India, and Spain; for solar PV modules, Chinese manufacturers supply $30 \%$ of the global market, followed by the United States, Japan, and more recently Canada (4.6\%) (REN21, 2013).

Since renewable energy support mechanisms also serve as inducements to invest in the eligible technologies and equipment, it is useful to consider the impacts on these manufactured product markets separately. In this case, renewable energy incentives like FITs create markets for these products that likely would not exist otherwise, except in limited specific applications where distributed generation is required, or to serve, voluntary demand programs. By privileging the local installation of these technologies, the FIT spurs demand - including for imported components.

However, the Ontario FIT sought to leverage a local generation subsidy to create a local manufacturing subsidy, in the form of the LCR. Because, unlike electricity, components compete in a global market, the LCR is more likely to distort trade than the FIT underlying it. In particular, as Ontario was not already a major player in wind or solar PV manufacturing, the LCR did constitute a significant investment incentive for manufacturing capacity that would not exist but for the LCR in combination with the FIT. A Canadian government report on the solar PV sector states plainly that the early leaders in Canadian-made modules 'are all located in Ontario in order to satisfy the Ontario domestic content requirements' (Navigant Consulting, 2012). However, it may be interesting to note that the net effect of the FIT program on Canadian imports of renewable energy components is unlikely to be negative, even with an LCR. Indeed, the same report highlights that all of the solar wafers/cells and many of the modules were sourced abroad. By contrast, it is production and trade in the non-privileged (fossil fuel) technologies that are more likely to suffer overall; however, more of that damage was done by the decision to phase out coal. ${ }^{18}$

\subsection{On the rationales for renewable energy subsidies}

Renewable energy policies enjoy broad public and governmental support around the world (including among the plaintiffs in this case). The foremost rationale for them is to reduce the threat of climate change, particularly since $42 \%$ of global carbon dioxide $\left(\mathrm{CO}_{2}\right)$ emissions from fossil fuel combustion come from electricity

18 US net exports of coal to Canada have declined substantially since 2008, due to these initiatives to reduce coal-fired generation (see http://www.eia.gov/todayinenergy/detail.cfm?id=8970). Of course, US coal consumption has also been declining because of a variety of factors. 
generation and heat production (IEA, 2013). Even though renewable energy deployment is only a partial solution, as it ignores opportunities to reduce the carbon content of non-renewable generation or increase conservation, political consensus forms much more readily around renewable energy incentives than comprehensive but controversial policies like carbon pricing. For this reason, the environmental community and many governments are particularly wary of potential impediments that WTO interpretations might create for 'green' subsidies.

Broad consensus also exists among countries that renewable energy support is a legitimate form of industrial policy. Indeed, the main plaintiff in this case, the EU, has its own ambitious targets laid out in the 20/20/20 Directive (EU, 2009a), ${ }^{19}$ and many of the official rationales given by the European Parliament were more related to jobs and trade than to climate policy: 'promoting the security of energy supply, promoting technological development and innovation and providing opportunities for employment and regional development, especially in rural and isolated areas ... [increasing] export prospects, social cohesion and employment opportunities ... [for small] independent energy producers' (EU, 2009b: 16).

Of course, in reality, many of the stated rationales merit closer scrutiny (Fischer and Preonas, 2010). Renewable sources typically do displace emitting sources, thus avoiding emissions both of $\mathrm{CO}_{2}$ and also of the conventional air pollutants most associated with coal-fired power generation, including sulfur dioxide $\left(\mathrm{SO}_{2}\right)$, the precursor of acid rain; $\mathrm{NO}_{x}$ and $\mathrm{SO}_{x}$, contributors to smog and respiratory problems; and mercury, which has been linked to nervous system impairments. However, the actual environmental effectiveness is highly sensitive to the amount and type of energy they displace, which varies by location, as well as the stringency and type of environmental regulation already in place. In fact, if emissions are already capped under an emissions trading system (as they are in the EU), overlapping renewable energy incentives will not produce any additional domestic reductions.

Energy security can play an important role in the support for renewable energy policies, particularly in regions (like Europe) that are heavily reliant on imported natural gas. While this strategy has political saliency among fossil fuel-importing nations, the degree to which increasing the share of renewable energy might actually insulate economies from volatilities in the global fossil fuel markets has been given little serious scrutiny (Sorrell, 2003). Furthermore, as with emissions reductions, promoting renewable energy is not the only means to meeting this goal; indeed, developing other energy sources or encouraging conservation also can reduce reliance on specific fuels that are subject to global price shocks or import disruptions.

19 This directive mandates that $20 \%$ of EU energy consumption come from renewable resources by 2020 , in addition to pursuing a $20 \%$ reduction in EU greenhouse gas emissions below 1990 levels and a $20 \%$ reduction in primary energy use. The multinational directive requires member states to enact their own incentive policies toward achieving individualized targets. 
One should also recognize that renewable energy sources entail their own forms of volatility, because of their reliance on intermittent natural energy sources, and their own external costs (Fischer and Preonas, 2010). The siting of renewable generation may affect landscape quality, both from the installation themselves and from the transmission lines needed to connect. Wildlife impacts may be of concern, as wind turbines have problems with bird strikes and noise pollution, and hydropower interferes with aquatic ecosystems. Biomass generation involves emissions of air pollutants. Solar panels can generate toxic waste, although the byproducts of the manufacturing process may be of greater concern (Nath, 2010). As with any energy source, there are trade-offs, and the costs and benefits are often specific to local areas.

Industrial policy, trade advantages, and skilled employment are other frequently stated goals of renewable energy policies. Denmark pursued an effective industrial strategy of heavily subsidizing wind power development in order to become a leading producer (Buen, 2006). Early renewable support in Germany enabled its firms to capture much of the world's wind energy market (Sorrell and Sijm, 2003). However, studies of these successes tend to avoid the questions of whether the benefits exceeded the cost of the policies (Fischer and Preonas, 2010) or how many early movers could simultaneously sustain an advantage. A Berkeley Roundtable report (Huberty et al., 2011) warns that 'the emphasis on export-led growth may risk a new green mercantilism more damaging than the growth it might create'. Even from a domestic perspective, the employment benefits are not clear. As FITs are demand-driving policies, they are relatively indirect means for stimulating domestic manufacturing once supply is globally competitive. The domestic job creation associated with FITs (absent an LCR) is more likely to center on construction, installation, and maintenance, with manufacturing focused on components that are more expensive to transport (such as wind towers). But the flip side of being a more labor-intensive energy source is that renewable energy is also a more costly energy source, thus placing a heavier burden on consumers (Kammen et al., 2004). The job promotion aspect of green industrial policies is thus less compelling as a rationale, unless one can argue that the political economy is such that the global environmental benefits achieved by the policy would not be possible but for the job creation aspects.

Perhaps the most compelling rationale for renewable energy production incentives, at least from an international perspective, is the prospect of bringing forth technological innovation, learning-by-doing, and scale economies. The idea is that scaling up production can help lower costs and enable the technologies to be more competitive vis-à-vis their dirtier counterparts, either directly through mass production and the competition it allows or indirectly through the technological advances that are induced by greater market potential and experience. To the extent that these cost reductions then encourage more countries to shift their energy use and reduce carbon emissions, the case for a climate benefit is much stronger (Fischer and Salant, 2014; Fischer et al., 2014). These factors could 
come into play in trade policy if the SCM Agreement were revised (or interpreted) to include an exception for environmental conservation, analogous to those detailed in Article XX of the GATT.

FITs, as typically designed, are attractive for addressing technology 'spillovers' (the excess social benefit above that which can be appropriated by private innovators through patents and the like), as they can tailor the degree of support according to learning potential. Technologies at earlier stages of development can be afforded larger premiums. For example, van Benthem et al. (2008) find that California's subsidies for solar, a less mature technology, are economically justified by learning spillovers, even though the environmental benefits fall short of the costs. However, technological progress also occurs via $\mathrm{R} \& \mathrm{D}$, which FITs support only indirectly by expanding the market for the fruits of innovation. Studies that account for technology market failures find that the market-correcting levels of production subsidies (from an innovation perspective) may be quite modest, particularly for wind generation, and emphasize the need for correcting R\&D incentives directly (Fischer et al., 2013; Fischer and Newell, 2008).

Other studies have identified additional technology barriers, such as path dependence, inertia, infrastructure factors, and market power, all of which can conspire to 'lock in' dominant conventional technologies (Sorell and Sijm, 2003; Schmidt and Marschinski, 2009). Strong, early renewables promotion and innovation can then enable a shift to a cleaner pathway. Typically, incentive-based policies must also be complemented by other approaches to overcome infrastructure and regulatory barriers (e.g., smart grids, interconnection requirements, transmission siting).

\section{Legal analysis of the renewable energy decision}

The Canada-Renewable Energy case is about two markets: (1) the market for renewable energy equipment production and investment, and (2) the market for electricity. The renewable energy equipment market is a global market, and Canada has allowed its province Ontario to erect discriminatory barriers against importation of those products (barriers that can only make renewable energy more costly in Canada). By contrast, the electricity market has traditionally been local, with cross-border electricity trade limited by geography and grid connection infrastructure. While the economic impact of a FIT may primarily be to incentivize investment in new renewable energy capacity and equipment installation, the policy is implemented with payments based on electricity generation.

In its decision, the Appellate Body addresses mainly the market for electricity, as that is where the subsidy would be legally defined. However, the decision makes a distinction between electricity from certain renewable sources and other generation. Indeed, the Appellate Body seems to split the market between those two sources. This is an important development, because electrical current from the two sources is physically identical and interchangeable in use. 
In this section, we first examine the substantive law on domestic market discrimination, then move to the substantive law of subsidy, and finally discuss the lack of openness by the Panel to non-state participation.

\subsection{TRIMS Agreement and GATT Article III}

Canada-Renewable Energy marked the first Appellate Body decision under the TRIMS agreement, thereby laying precedents for future jurisprudence on the application of the TRIMS non-discrimination disciplines. The Appellate Body reversed the Panel so as to reduce the scope of the derogation for government procurement in GATT Article III. This holding has implications for TRIMS because that agreement and GATT Article III are so closely interconnected. ${ }^{20}$

The Panel began its evaluation under the TRIMS Agreement by considering whether the FIT program was in fact an investment program, and, if so, whether it was trade-related. (Canada did not contest that the measure fit within the scope of the TRIMS Agreement.) A previous Panel, Indonesia-Autos in 1998, took the same approach, but the Autos Panel decided that the contested measure was an investment measure based on its announced purpose and legislative text. ${ }^{21}$ By contrast, the Renewable Energy Panel decided that the FIT was an investment measure not only based on the legislative record, but also considering the evidence that Ontario's scheme had in fact attracted investment in equipment manufacturing. Like the Autos Panel, the Renewable Energy Panel found that the investment measure was trade-related based on its minimum local content requirement. These findings were not reviewed by the Appellate Body.

The TRIMS Agreement lacks any substantive disciplines independent of the GATT; therefore, evidencing a violation of GATT Article III or XI is necessary to show a violation of TRIMS Article 2. Ontario's measure was not a quantitative restriction, so if there was a violation of GATT, it had to be a violation of Article III:4 (national treatment). The key question before the Panel was how to apply the language in Article III:8(a), which carves out from the disciplines of Article III certain activity related to government procurement; ${ }^{22}$ the Appellate Body refers to Article III:8(a) as a 'derogation'. ${ }^{23}$

Canada's defense to the cause of action under TRIMS was based solely on Article III:8(a); namely, that due to the nature of the program being a market created by and

20 Note that Canada did not offer an Article XX defense to the GATT or TRIMS causes of action.

21 Panel Report, Indonesia - Certain Measures Affecting the Automobile Industry, WT/DS54/R, WT/DS55/R, WT/DS59/R, WT/DS64/R, adopted 23 July 1998, para. 14.80.

22 GATT Article III(a) states: 'The provisions of this Article shall not apply to laws, regulations or requirements governing the procurement by governmental agencies of products purchased for governmental purposes and not with a view to commercial resale or with a view to use in the production of goods for commercial sale.'

23 Appellate Body Report, Canada-Renewable Energy/Canada-Feed-In Tariff Program, para. 5.56 (noting that this term does not indicate who bears the burden of proof). 
for the government and its entities, it was not subject to Article III's obligations. The EU offered an expansive reading of TRIMS Article 2.2 and the TRIMS Illustrative List that suggested a discriminatory measure on the Illustrative List could be found to be a violation of GATT Article III:4 irrespective of the Article III:8 procurement derogation. In its decision, the Panel rejected that argument, and its analysis was upheld by the Appellate Body. ${ }^{24}$ In doing so, the Appellate Body suggested it was a providing a 'harmonious' interpretation of TRIMS Articles 2.1 and 2.2 together. $^{25}$ Moreover, the Appellate Body held that the TRIMS Illustrative List is not a closed list and that GATT Article III:8(a) provides 'rights' to WTO Members. ${ }^{26}$

Thus, the availability of Article III's procurement derogation was the central feature of the TRIMS and GATT analysis. This question was nearly a tabula rasa for the WTO dispute system, as no previous WTO jurisprudence on GATT Article III:8(a) had occurred. As a result, both the Panel and the Appellate Body devoted considerable attention to the interpretation of Article III:8(a). Although the Appellate Body upheld the Panel's conclusion that the challenged measure did not fit within the terms of the Article III:8(a) derogation, it declared that the Panel had erred on a key analytical point.

In determining the applicability of GATT Article III, the Panel divided the analysis into three prongs: first, whether the measure is a law, regulation, or requirement governing procurement; second, whether the measure involves procurement by governmental agencies; and third, whether the procurement is undertaken for governmental purposes and not with a view to commercial resale. On the first prong, the Panel found that the domestic content requirement for renewable energy equipment is a requirement governing the procurement of electricity because there is a 'very clearly a close relationship' between the electricity allegedly being procured and the domestic content requirement on energy generation equipment. ${ }^{27}$ On the second prong, the Panel found that the measure constitutes procurement by government agencies. On the third prong, the Panel reasoned that if the purchase had been done with a view to commercial resale, then such a purchase cannot be for governmental purposes. ${ }^{28}$ Focusing on the issue of commercial resale, the Panel considered and rejected several arguments by Canada that the nature of the market undermined the commercialness of the sale. Consequently, the Panel ruled that the resale of electricity produced through the FIT program is 'commercial' and that the government indeed earns a profit. ${ }^{29}$ Thus, the Canadian Article III:8(a)

24 Panel Report, Canada-Renewable Energy/Canada-Feed-In Tariff Program, para. 7.120; Appellate Body Report, para. 5.33.

25 Appellate Body Report, Canada-Renewable Energy/Canada-Feed-In Tariff Program, para. 5.26.

26 Ibid., paras. 5.22, 5.32 .

27 In the preliminary part of its report, the Panel noted that no party had contested that electricity is a good. The Panel's Report assumes that electricity is a good, even noting its intangible nature. Panel Report, para. 7.11 , n. 46 , para. 7.127.

28 Ibid., para. 7.145.

29 Ibid., para. 7.151. 
defense was found to have failed on the third prong, and the Panel did not rule on the existence of 'governmental purposes'.

The applicability of the Article III:8(a) defense was appealed by all three parties. Explaining that Article III:8(a) was a derogation rather than a justification, the Appellate Body provided what it called a 'holistic' interpretation of the key terms in Article III:8(a). ${ }^{30}$ The Appellate Body's dicta will surely guide future Panels. ${ }^{31}$ The most important conclusion reached by the appellators was that since both the obligations in Article III and the derogation in III:8(a) refer to discriminatory treatment of products, the same discriminatory treatment must exist with both rules. ${ }^{32}$ Put another way, the product of foreign origin being discriminated against must be in a competitive relationship with the product purchased by the government. 33

Applying its interpretation to the facts, the Appellate Body noted that the discriminatory treatment (in the form of minimum content) applies to renewable energy equipment, while the government procurement concerns electricity. Since electricity is not the same as, or a competitive product to, the electricity generating equipment that is being treated less favorably, the Appellate Body reversed the Panel on the first prong, holding that the discriminatory measures were not covered by the Article III:(8)(a) derogation. The Appellate Body also reversed as 'moot' all of the other legal interpretations by the Panel of Article III:8(a). ${ }^{34}$

The remainder of the Panel's finding with regard to TRIMS Article 2.1 and Article III:4 was not challenged by Canada on appeal, and the Appellate Body

\subsection{2 .}

30 Appellate Body Report, Canada-Renewable Energy/Canada-Feed-In Tariff Program, paras. 5.56,

31 Dicta is used here in the sense that the Appellate Body extensively interpreted Article III:8(a), even though these findings were unnecessary in its conclusion to reverse the Panel on the first prong. See Appellate Body Report, Canada-Renewable Energy/Canada-Feed-In Tariff Program, para. 5.84. Among the key points were that procurement should not be equated with purchase; that the definition of a government agency is determined by the competences conferred and on whether the entity acts for or on behalf of the government; that what constitutes a competitive relationship between products may require consideration of inputs and processes of production used to produce the product; that there has to be a 'rational relationship' between the product purchased and the governmental function being discharged; and that where products are consumed for government use, the consumption does not have to be immediate or ultimate. The Appellate Body also provided an essentially economic analysis on the meaning of commercial resale, noting that any profit orientation needs to be examined from the perspective of both the seller and the buyer, and introduced without any textual basis the concept of an arms-length sale. Ibid., paras. 5.71, 5.74. The Appellate Body also disagreed with the Panel's view of the third prong as disjunctive, maintaining that the two requirements in the third prong are cumulative. Ibid., para. 5.69. On the issue of the meaning of the term 'government agency' in Article III:8(a), the Appellate Body posited that 'GATT 1994 recognizes that there is a public realm and a private realm, and that government entities may act in one, the other, or both'. Ibid., para. 5.61.

32 Appellate Body Report, Canada-Renewable Energy/Canada-Feed-In Tariff Program, para. 5.63. The Appellate Body's restatement of Article III:8(a) is summarized in ibid., para. 5.74.

33 Ibid., para. 5.79.

34 Ibid., paras. 5.82, 6.1(b)(ii). 
made clear that this part of the Panel's analysis 'stands'. ${ }^{35}$ Specifically, based on its conclusion that Article III:8(a) did not apply, the Panel had analyzed the Ontario measure under Article III:4. The Panel found that mere participation in the FIT program was an 'advantage' under the chapeau of Article 1(a) of the TRIMS Illustrative List and that compliance with the domestic content requirements was necessary in order to obtain this advantage. ${ }^{36}$ Therefore, the Panel concluded that the domestic content requirement of the FIT was inconsistent with Article III:4 and thereby also inconsistent with TRIMS Article 2.1.37 These findings were upheld.

\subsection{SCM Articles 1 and 3}

The cause of action against the FIT contracts was that they violate SCM Article 3.1 (b), which forbids providing a subsidy contingent on local content. In adjudicating this claim, neither the Panel nor the Appellate Body reached this central issue, because neither was able to validate the existence of a subsidy. The SCM Agreement defines a subsidy in Article 1 as generally requiring the two prongs of a financial contribution from the government and a benefit to a recipient. Alternatively, a subsidy can also be shown if, instead of a financial contribution, there is 'any form of income or price support in the sense of' GATT Article XVI (notification of subsidies). ${ }^{38}$ If found to be a subsidy, then in view of the embedded LCR, the Ontario FIT would automatically be prohibited under the SCM Agreement. (A separate question, not addressed in the adjudication, would ask whether a FIT without an LCR would be specific and actionable under the SCM Agreement with regard to trade in electricity.)

A key issue in this case was how, if at all, Ontario's FIT contracts come within the statutory definition of financial contribution'. The SCM definitional provisions are as follows:

[A] subsidy shall be deemed to exist if:

(a)(1) there is a financial contribution by a government or any public body within the territory of a Member (referred to in this Agreement as 'government'), i.e. where:

(i) a government practice involves a direct transfer of funds (e.g. grants, loans, and equity infusion), potential direct transfers of funds or liabilities (e.g. loan guarantees);

(ii) government revenue that is otherwise due is foregone or not collected (e.g. fiscal incentives such as tax credits),

35 Ibid., para. 5.85 .

36 Panel Report, Canada-Renewable Energy/Canada-Feed-In Tariff Program, para. 7.165.

37 Ibid., para. 7.117.

38 The condition 'in the sense of' presumably refers to the language of GATT Article XVI:1 which references a subsidy 'including any form of income or price support, which operates directly or indirectly to increase exports of any product from, or to reduce imports of any product into, its territory'. 
(iii) a government provides goods or services other than general infrastructure, or purchases goods;

(iv) a government makes payments to a funding mechanism, or entrusts or directs a private body to carry out one or more of the type of functions illustrated in (i) to (iii) above which would normally be vested in the government and the practice, in no real sense, differs from practices normally followed by governments. ${ }^{39}$

All three litigants agreed that the contracts were financial contributions, but the three governments offered different views as to the proper legal characterization between (i) and (iii) above.

The Appellate Body (as well as the Panel) concluded that the contracts manifested a government purchase of goods, and, therefore, a financial contribution exists. ${ }^{40}$ In reaching that outcome, the Panel scrutinized the design, operation, and principal characteristics of the contracts and concluded that the Ontario Power Authority pays for delivered electricity and that Ontario's Hydro One takes possession of the electricity. The Panel also noted that, for electricity, the purchase of electricity means the transfer of the entitlement to the electricity. ${ }^{41}$

Both the Panel and the Appellate Body also grappled with the question of whether a measure could be a financial contribution in more than one way under the SCM definition. Japan had argued that the measures constituted a 'direct transfer of funds' or a 'potential direct transfer of funds', but the Panel reasoned that a purchase of goods could not simultaneously be a 'transfer of funds', as that logic would render all purchases of goods to duplicatively be direct transfers of funds. ${ }^{42}$ This legal holding of mutual exclusivity was declared 'moot and of no legal effect' by the Appellate Body, as being inconsistent with a previous Appellate Body ruling that the definition of financial contribution does not expressly exclude that a transaction could be covered by more than one subparagraph of the definition. ${ }^{43}$ Nevertheless, the Appellate Body refused to agree with Japan that the measure should also be characterized as a direct transfer, or a potential direct transfer, of funds. ${ }^{44}$

39 SCM Article 1.1(a)(1).

40 Japan, one of the plaintiffs, appealed the Panel's finding that Ontario's electricity contracts were purchases of a good, but the Appellate Body upheld the Panel. Appellate Body Report, CanadaRenewable Energy/Canada-Feed-In Tariff Program, para. 5.128.

41 Panel Report, Canada-Renewable Energy/Canada-Feed-In Tariff Program, para. 7.229.

42 Ibid., paras. 7.245-7.246. The Panel noted that the Appellate Body had previously stated that SCM Article 1.1 did not expressly preclude that a transaction could be covered by more than one subparagraph. Ibid., 7.247. Nevertheless, the Panel seemed to adopt an interpretation that denied that a transaction could be covered by two subparagraphs. The Appellate Body was quick to point out the inconsistency with its prior jurisprudence and responded by erasing the legal effect of the Panel's finding. Appellate Body Report, Canada-Renewable Energy/Canada-Feed-In Tariff Program, para. 5.121.

43 Appellate Body Report, Canada-Renewable Energy/Canada-Feed-In Tariff Program, para. 5.121.

44 This portion of the Appellate Body decision is murky. The Appellate Body seems to be suggesting that the proper legal characterization depends on the order in which the judge considers the prongs as defining a financial contribution. Ibid., para. 5.131. Such a conclusion seems illogical to us, particularly 
Japan (backed to some extent by the EU) argued before the Panel that the FIT contracts constitute 'income or price support' of electricity. ${ }^{45}$ Only one previous WTO case before Renewable Energy had considered this income or price support' provision, and the Renewable Energy Panel dodged the issue by exercising judicial economy. Japan appealed this non-finding, but the Appellate Body rejected the claim of false judicial economy. In exercising judicial economy, the Panel peeked ahead to the next section of its report and noted that since the Panel majority 'rejects the entirety' of the conclusion that a benefit exists from the financial contribution, there was no need to determine whether a benefit exists from the income or price support. ${ }^{46}$ In upholding the Panel, the Appellate Body noted that Japan had not explained how the benefit analysis could have come out differently if the Panel had characterized the FIT as an income or price support. ${ }^{47}$ Thus, the Appellate Body's conclusion might have been different if Japan had been more comprehensive in its pleadings. ${ }^{48}$

The second part of the definition of a subsidy requires that the financial contribution confer a benefit to a recipient. The Appellate Body agreed with the Panel that the appropriate legal standard for a benefit is whether the FIT recipient has received the financial contribution on terms more favorable than those available to the recipient in the market. ${ }^{49}$ In this case, the generators of electricity who are party to the FIT contracts are the recipients. So the question is whether the terms of the contract provide more than 'adequate remuneration'. Even though their governments also provide generous FITs, both the EU and Japan argued on appeal that in the absence of the FIT contracts, the solar and wind power electricity generators would not have been able to operate financially. ${ }^{50}$ Thus, from that perspective, the lucrative payments made by the Ontario government to the generators clearly provide a benefit.

Nevertheless, this straightforward conclusion was rejected by the Appellate Body, which refused to adopt such a 'but for' test in favor of a more government-centric market analysis. Although the Panel had not ascertained the existence of a benefit, the Appellate Body reversed the Panel's conclusion as having been

in light of the Appellate Body holding that the prongs are not mutually exclusive. Moreover, if the same characteristics of a measure cannot do double duty in qualifying a measure as a financial contribution under more than one of the Article 1.1(a)(1) prongs, the Appellate Body does not explain its reason for considering the prongs out of order rather than seriatim.

45 Panel Report, Canada-Renewable Energy/Canada-Feed-In Tariff Program, para. 7.172.

46 Ibid., para. 7.249. The Panel averred that the case arguments for the existence of benefit were 'essentially parallel' as between the two provisions. Ibid., para. 7.249.

47 Appellate Body Report, Canada-Renewable Energy/Canada-Feed-In Tariff Program, para 5.137.

48 Japan fails to make its pleadings publicly available, so we were not able to verify the Appellate Body's contention.

49 The SCM Article 1 standard is whether there is a benefit to the recipient. Whether such a benefit is congruent with economic rent has not been addressed in the jurisprudence.

50 Appellate Body Report, Canada-Renewable Energy/Canada-Feed-In Tariff Program, paras. 5.194-5.196. 
based on an erroneous analytical application of the proper legal standard. ${ }^{51}$ In particular, according to the Appellate Body, the Panel had erred in considering the wholesale market for all electricity from any source as the relevant market. ${ }^{52}$ Instead, the Appellate Body ruled that the relevant market was electricity produced from wind and solar generators. Its ruling was based on the assertion that both the government and some consumers view these products as being different from conventional generation. The Appellate Body indicated that the Panel had not sufficiently considered such supply- and demand-side factors specific to the provincial market. ${ }^{53}$

The market for renewably sourced electricity, according to the Appellate Body, can come into existence only as a matter of government regulation, particularly the government's choice of the appropriate supply mix of electricity generation technologies. ${ }^{54}$ The Appellate Body declared that a government may choose its supply mix by setting administered prices or by requiring private distributors or the government itself to buy part of their electricity from certain generation technologies. Without offering any reasons, the Appellate Body further emphasized that a regulation defining the government's desired supply mix 'cannot in and of itself be considered as conferring a benefit' under the SCM Agreement'. ${ }^{55}$ Indeed, the Appellate Body made this point three times, each without offering any justification. ${ }^{56}$

To summarize the Appellate Body's conclusion, the judge should start with the 'policy imperatives' such as 'reducing reliance on fossil fuels', and then consider how the government defines the energy supply mix. That constructivist definition denotes a 'market' for electricity from certain renewable energy, and that market is then used to determine the existence of a benefit. Acknowledging the difference between its analytical approach and an approach based on observing an actual

51 Ibid., para. 5.219.

52 The Panel had rejected assuming the existence of a renewable electricity market on the grounds that Ontario's consumers do not distinguish electricity on the basis of different generation technologies and that the physical properties of electricity do not change depending on the process of generation. Panel Report, Canada-Renewable Energy/Canada-Feed-In Tariff Program, para. 7.318. The Panel also said that the market for analysis has to be determined by supply and demand, and not by means of government intervention that renders the SCM definition of benefit circular. Ibid., para. 7.275.

53 Appellate Body Report, Canada-Renewable Energy/Canada-Feed-In Tariff Program, para. 5.214. The key supply-side factor is that electricity from renewable energy cannot compete with other electricity from conventional sources. The key demand-side factor is the government as market participant. The Appellate Body criticized the Panel for focusing too much on the preferences of final consumers while ignoring the government's preferences. Oddly, the Appellate Body also says that the government's purchase decisions may reflect the fact that consumers are ready to purchase more expensive electricity from renewable sources. Ibid., para. 5.177.

54 Ibid., para. 5.175.

55 Ibid.

56 Ibid., paras. 5.175, 5.227, 5.190 (does not constitute a subsidy). The Appellate Body further explained that 'the creation of a market by a government does not in and of itself give rise to subsidies'. Ibid., para. 5.188. 
market, the Appellate Body admitted that while introducing legitimate policy considerations into the determination of 'benefit' could not be reconciled with the SCM Article 1 text, its self-described market-based approach to benefit benchmarks did not exclude taking into account situations where governments intervene to create markets that would not otherwise exist. ${ }^{57}$

Thus, to determine whether the FIT contracts confer a benefit, the Appellate Body explained that the benchmarks for comparison should be the terms and conditions that would emerge from market-based conditions for each of these technologies, taking the government-determined supply mix as a given. In other words, the relevant question is whether wind and solar electricity suppliers would have entered the renewable electricity market given those targets but absent the FIT program, not whether they would have entered the blended electricity wholesale market without the subventions.

After laying out its desired analytical approach, the Appellate Body found error in the Panel's overreliance on the arguments of the complainants and in its failure to undertake its own analysis of the proper market. ${ }^{58}$ In dicta, the Panel had recognized that a competitive wholesale electricity market could not be the appropriate focus for a benefit analysis, because such a market would not attract sufficient investment in clean energy. ${ }^{59}$ Yet, although the complainants had invited it to conduct its own analysis, the Panel had demurred on the grounds that a Panel is not entitled to make a prima facie case for a complainant. ${ }^{60}$ Nevertheless, the Panel did offer its own 'observations' on the issue of benefit. ${ }^{61}$ It was such dicta that provided the hook for the Appellate Body to reverse the Panel for not having pursued its own line of reasoning to a conclusion.

57 Ibid., para. 5.185. In that regard, the Appellate Body drew a distinction between 'government interventions to create markets that would otherwise not exist and, on the other hand, other types of government interventions in support of certain players in markets that already exist or to correct distortions therein'. Ibid., para. 5.188. In a previous case, in discussing SCM benefit, the Appellate Body had called for using 'the market standard - according to which rational investors act'. Appellate Body Report, Japan - Countervailing Duties on Dynamic Random Access Memories from Korea, WT/DS336/AB/R and Corr.1, adopted 17 December 2007, para. 172. Perhaps in the FIT case, the Appellate Body was suggesting that rational actors would pay a higher price for electricity that is sourced from renewable energy.

58 Appellate Body Report, Canada-Renewable Energy/Canada-Feed-In Tariff Program, para. 5.219. Canada had urged the Panel to find the appropriate benchmark in the market for electricity produced from wind or solar energy.

59 Panel Report, Canada-Renewable Energy/Canada-Feed-In Tariff Program, paras. 7.320, 7.312, $7.313(\mathrm{c})$.

60 Ibid., para. 7.321.

61 For example, the Panel suggested comparing the FIT contracts to the conditions that commercial distributors of electricity might have paid if there were a government obligation to purchase renewable energy. Ibid., para. 7.322. The Panel also suggested comparing the rate of return on FIT investments to the average cost of capital for projects in Canada with a comparable risk profile in order to see whether FIT generators were being overcompensated. Ibid., para. 7.323. 
While the Appellate Body did not appear to disagree with the Panel that the complainants had failed to establish the existence of benefit, it nevertheless reversed the Panel's holding of a failure to demonstrate the benefit. ${ }^{62}$ This puzzling outcome can be explained only if the Appellate Body had been saying that the complainants had actually put forward a prima facie case, despite using the wrong benchmark and that the Panel had an obligation to seek whatever information was needed to conduct the analysis with a correct benchmark. ${ }^{63}$ Moreover, the Appellate Body seems to have been saying that despite the complainants' obligation to identify the suitable benchmark, that obligation could be fulfilled by presenting arguments that in some way touch on a benchmark that was not offered by the complainants. ${ }^{64}$

After reversing the Panel's conclusion that the complainants had failed to establish that the FIT conferred a benefit, the Appellate Body considered whether it had sufficient factual findings on the record to complete the analysis. The Appellate Body concluded that it did not have such facts, but it nevertheless offered dicta on how a judge might make such a determination. The Appellate Body explained that first one should look for what a market benchmark would yield for windand solar-generated electricity in Ontario. If needed, one could look for an appropriate benchmark outside of Ontario. The Appellate Body further observed that the fact that the government sets prices does not in itself establish the existence of a benefit. Rather, the complainant must show that the prices do not reflect the adequate remuneration that would result in the market, and a complainant might do so with an analysis of the methodology that was used to establish the administered prices. Where there is not sufficient information, the next step could be to construct a proxy within the country or in another country, provided that the proxy is determined based on a price-setting mechanism. The Appellate Body pointed to price discovery mechanisms such as competitive bidding or negotiated prices to ensure that the price paid by the government is the lowest possible price offered by a willing supply contractor. ${ }^{65}$ In addition, the Appellate Body hinted that for wind-based electricity, there was evidence that FIT contracts confer a benefit in comparison to Ontario's wind-power generation contracts awarded by the government with competitive bidding. ${ }^{66}$

We have summarized the Appellate Body's roadmap for how a Panel should conduct the benefit analysis in future FIT cases in Table 1.

The Appellate Body did not analyze or rebut the noteworthy dissenting opinion in the Panel Report, which emphasized previous Appellate Body jurisprudence

62 Appellate Body Report, Canada-Renewable Energy/Canada-Feed-In Tariff Program, para. 5.219. 63 Ibid., paras. 5.215, 5.219.

64 Ibid., paras. $5.215,5.216$.

65 Ibid., para. 5.288, 5.233.

66 Ibid., para. 5.241 . 
Table 1. Appellate body's suggested hierarchy for selecting the comparator for benefit analysis

\begin{tabular}{|c|c|}
\hline Source of benchmark & Options for determining relevant market price \\
\hline 1. In-country benchmark & $\begin{array}{l}\text { a. Market prices } \\
\text { b. Administered prices determined based on price-setting } \\
\text { mechanism } \\
\text { c. Administered prices set through price discovery } \\
\text { mechanism such as competitive bidding or negotiated } \\
\text { prices }\end{array}$ \\
\hline $\begin{array}{l}\text { 2. Out-of country benchmark when } \\
\text { government intervention is distortive }\end{array}$ & $\begin{array}{l}\text { Same options, adjusted to prevailing conditions in the } \\
\text { market of the of the defendant country }\end{array}$ \\
\hline 3. Proxy construction & $\begin{array}{l}\text { Appellate Body does not elaborate but presumably an } \\
\text { analysis based on costs plus profit }\end{array}$ \\
\hline
\end{tabular}

regarding the marketplace. ${ }^{67}$ The dissenting judge had found that the FIT contracts do confer a benefit, because they bring high-cost and less-efficient energy producers into the wholesale electricity market when they would not otherwise be present. ${ }^{68}$ In addition, that anonymous jurist pointed out that although a competitive market might not achieve all of the objectives that the government may have for the goods or services that are traded, that situation should not shield the related financial contributions from the benefit analysis required by the SCM Agreement.

\subsection{Procedural issues}

Apart from these developments in substantive trade law, four procedural aspects of the case deserve attention. First, the Appellate Body abandoned its past practice of using a paragraph numbering system distinct from that regularly used by Panels. The clever decimal-based numbering system had started with the EC-Bananas ${ }^{69}$ case in 1997 and saved trade law practitioners countless hours by clearly delineating Panel versus Appellate Body rulings. The Appellate Body provided no explanation for why it adopted such a significant change that certainly does not serve the cause of clarity in WTO jurisprudence. This episode provides yet another example of why the Appellate Body should adopt a notice and comment process before making changes in its rules and practices.

Second, at the Dispute Settlement Body (DSB) meeting considering the reports, Canada complained that the Appellate Body's interpretation of GATT Article

67 Ibid., para. 5.196. Several governments, including the parties and third participants Australia and Brazil, commented approvingly on the anonymous dissenting opinion.

68 Panel Report, Canada-Renewable Energy/Canada-Feed-In Tariff Program, para. 9.23.

69 Appellate Body Report, European Communities - Regime for the Importation, Sale and Distribution of Bananas, WT/DS27/AB/R, adopted 25 September 1997. 
III:8 was not based on the submissions of the parties and that no questions about the incipient interpretation were put to the parties. ${ }^{70}$ If true, this claim does raise significant due process concerns. On the other hand, in a common law system, a court is not limited to the legal arguments offered by the litigants.

A third procedural point involves amicus briefs. Given the importance of the dispute to the global environment, the Panel received two sets of amicus curiae briefs from non-governmental organizations (NGOs): one from a coalition of labor groups and one from a coalition of environmental groups. Consistent with past practice of Panels, the Panel identified the NGOs but did not append the briefs or summarize their content. In addition, the Panel delegated to the governments the question of whether it should take the briefs into account. When no government signified that the Panel should take the briefs into account by appending the non-governmental briefs to the government submission, the Panel reported in its decision that it 'did not find it necessary to take the briefs into account'. ${ }^{71}$

The Appellate Body noted that it received two amicus briefs: one from an energy company and one from an academic. ${ }^{72}$ The Appellate Body did not identify the sources of these briefs and did not discuss their content. According to the report, the division gave the participant and third participant governments an opportunity to express their views on these briefs at the oral hearing, but the report does not discuss the extent to which the participants did so.

We take note of the Panel's sense of self-assurance in juxtaposition to how its adjudication was dispatched by the reviewing court. The Appellate Body reversed the Panel twice, declared moot its findings once, and criticized it several times. The Panel was composed of distinguished individuals, but one wonders whether the Canada-Renewable Energy Panelists would have done a better job for the parties and the WTO if they had exercised their prerogative to take the amicus briefs into account. ${ }^{73}$ In our view, Panels should regularly take advantage of the legal insights offered in amicus briefs from NGOs, academics, or others.

Fourth, this case provides yet another example showing the need for a remand procedure in the DSU. As noted above, the Appellate Body concluded that there were not sufficient factual findings by the Panel and uncontested evidence on the Panel record to allow the Appellate Body to determine whether the FIT confers a benefit. As a result, the DSB's work in this case remained undone. Although we favor the establishment of a remand procedure, we note that in instances where the Appellate Body is unable to complete the analysis, the complainants are always free to file a new case. The fact that complainants regularly do not do

70 DSB Meeting Held on 24 May 2013, WT/DSB/M/332, para. 8.4.

71 Panel Report, Canada-Renewable Energy/Canada-Feed-In Tariff Program, para. 1.13.

72 Appellate Body Report, Canada-Renewable Energy/Canada-Feed-In Tariff Program, para. 1.30. The unidentified academic was Luca Rubini.

73 See Rubini (2014: 11-12) for similar criticism of the Panel's and Appellate Body's disposition against use of the amicus briefs. 
so may suggest the need for a procedure triggered by a motion of the complainant rather than giving the Appellate Body full discretion to institute a remand.

\section{Policy implications}

The Canada-Renewable Energy case adds to the already rich body of WTO environmental jurisprudence and to the much smaller corpus of energy law jurisprudence. ${ }^{74}$ Given the renewable energy issues at hand, the environmental policy and advocacy community, several of whom already view the WTO with some skepticism, watched the case closely. While a few North American groups (Public Citizen and the Sierra Club, as well as local trade unions) did argue in favor of the local content requirements being a legitimate part of a sustainable growth strategy, the primary concern was that the WTO should not hamper the governments' ability to implement clean energy policy. In the end, the Appellate Body did vitiate the LCR without declaring the FIT itself a WTO violation. However proper that result, did the appellators reach that conclusion with the right analysis? The specific reasoning can have implications going forward, not only for renewable energy policy, but also for a host of incentive programs that governments might undertake for reasons of social welfare and industrial policy unrelated to the environment. Below, we discuss the significance of this case for the definition of 'like' products for carrying out the SCM Agreement, and for the WTO itself.

\subsection{PPMs, like products, and the role of preferences}

So far, one of the core issues in the trade and environment debate, the issue of process and production methods (PPMs) in 'like' products, has received little explicit attention in WTO case law. Canada-Renewable Energy ushers in the question of how the WTO should treat electricity produced from clean energy versus electricity produced from fossil fuels. Previous cases have made determinations regarding PPMs and 'like' products, but not their intersection (Charnovitz, 2002). In US-Shrimp, ${ }^{75}$ the United States had disallowed shrimp imports based on the PPM prescribed and used in the foreign country whose fishing vessels were harvesting the shrimp. When the US law was challenged, the Appellate Body ruled that the environmental exceptions in GATT Article XX applied. ${ }^{76}$ Because this case did not then hinge on Article I, the question of like product did not arise.

74 On energy law, mainly the China-Raw Materials case and the GATT-era US-Auto Taxes cases.

75 Appellate Body Report, United States - Import Prohibition of Certain Shrimp and Shrimp Products, Recourse to Article 21.5 of the DSU by Malaysia, WT/DS58/AB/RW, adopted 21 November 2001.

76 Appellate Body Report, US-Shrimp (Article 21.5-Malaysia), para. 121 (stating that 'conditioning access to a Member's domestic market on whether exporting Members comply with, or adopt, a policy or policies unilaterally prescribed by the importing Member may, to some degree, be a common aspect of measures falling within the scope of one or another of the exceptions (a) to (j) of Article XX'). 
The GATT acquis on the meaning of 'like products' has always identified 'consumers' tastes and habits' as being one deciding factor as to whether two products are like. The Appellate Body affirmed this principle in EC-Asbestos, ${ }^{77}$ noting that consumers may indeed have preferences regarding the carcinogenic content of their cement. ${ }^{78}$ Asbestos, of course, was about product characteristics and not PPMs, but that case stands for the proposition that the health implications of using a product are, in part, determinative of a product's likeness under GATT rules.

The nature of PPMs is that one cannot peer into the product to see its production method. For example, one cannot examine tuna to see if was caught with dolphins; one cannot examine shrimp to see if it came from a country that requires turtle excluder devices; one cannot examine a polished diamond to see if it was mined in a region of conflict. Similarly, one cannot examine electricity to know the source of particular kilowatt delivered by the grid. Indeed, one cannot even see the electricity.

The Canada-Renewable Energy decision clarifies that electricity is a 'good', but it does not specifically address whether electricity from certain clean energy sources is not a 'like' product to electricity from carbon-intensive (or other non-favored sources of) energy. ${ }^{79}$ (Indeed, the Panel does not seem to address whether imported and domestic renewable energy equipment are like products.) Nevertheless, the Appellate Body and Panel Reports do make some points relevant to the overall question of PPMs.

Although the Panel had considered the relevant market for ascertaining an SCM benefit to be electricity from any source of power, the Appellate Body held that the proper market was the so-called 'competitive markets for wind and solar PV-generated energy'. ${ }^{80}$ The Appellate Body reached this conclusion by considering both demand- and supply-side factors, in particular the demand coming from the government as buyer. The Appellate Body also noted that the government's preferences may reflect that 'consumers are ready to purchase electricity that results from the combination of different generation technologies, even if this is more expensive than electricity that is produced exclusively from conventional generation sources' ${ }^{81}$

77 Appellate Body Report, European Communities - Measures Affecting Asbestos and AsbestosContaining Products, WT/DS135/AB/R, adopted 5 April 2001.

78 Appellate Body Report, EC-Asbestos, para. 145 (stating, 'We consider it likely that the presence of a known carcinogen in one of the products will have an influence on consumers' tastes and habits regarding that product ... We are of the view that a determination on the 'likeness' of the cement-based products cannot be made, under Article III:4, in the absence of an examination of evidence on consumers' tastes and habits').

79 The Appellate Body does say that the comparison to the benchmark needs to be 'for the same product'. Appellate Body Report, Canada-Renewable Energy/Canada-Feed-In Tariff Program, para. 5.228 .

80 Ibid., para. 5.178.

81 Ibid., para. 5.177. 
In our view, the relevant market for the determination and calculation of a benefit under SCM Articles 1 and 14 should also be the appropriate electricity market for analysis of discrimination under GATT Articles I and III. Therefore, in a hypothetical dispute about electricity trade, if a competitive market for the purposes of SCM analysis must take into account consumer (and government as consumer) demand for clean energy, then should not the market for the purposes of GATT Article III:2 and 4 also take that consumer demand into account? If electricity from clean energy is a 'like' product to electricity from conventional energy, then the two types of electricity are in competition with each other in the same market. By contrast, if the market for clean energy is distinct from the market for conventional energy pursuant to Article 1 of the SCM Agreement, then that situation is pregnant with implications for the definition of products in GATT Articles III and VI (Anti-dumping and Countervailing Duties). For example, is a widget made using solar-sourced electricity a like product to a widget from using coal-fired electricity? At the very least, this SCM ruling provides new ammunition to those who will put more weight on the consumer preference factor in ascertaining how to treat PPMs under GATT Article III.

The Appellate Body also makes a statement with seeming relevance to PPMs in its analysis of GATT Article III. In its discussion of the scope of Article III:8, the Appellate Body declared that "what constitutes a competitive relationship between products may require consideration of inputs and processes of production used to produce the product'. ${ }^{82}$ The meaning of this statement is not clear, but the Appellate Body immediately follows it with a reference to a point made by the European Union that government procurement policy could take into account 'the environmental profile' of a product, meaning not only physically detectable characteristics, but also attributes that do not materialize into any particular physical characteristic. ${ }^{83}$ What the EU meant is not clear either, but at the very least these inscrutable passages merit more attention.

\subsection{Nature of the intervention used}

In having characterized the FIT financial contribution as a governmental purchase of a good, both the Panel and Appellate Body battled with whether the purchase was for adequate remuneration. If the FIT had been treated as a direct transfer of funds by the government, then the finding of benefit would have been nearly automatic. ${ }^{84}$ The Panel offered a principled reason for not holding so-namely, that a government purchase could not also be a direct transfer of funds merely

82 Ibid., para. 5.63; see also para. 5.74, n. 523. On this point, some commentators have called attention to the 'resulting insecurity' (Hestermeyer and Nielsen, 2014: 578).

83 Ibid., para. 5.63 n. 499.

84 See Panel Report, European Communities and Certain Member States - Measures Affecting Trade in Large Civil Aircraft, WT/DS316/R, adopted 1 June 2011, as modified by Appellate Body Report, WT/ DS316/AB/R, para. 7.1501. 
because the government pays for the purchase with funds. ${ }^{85}$ Nevertheless, the Appellate Body was quick to overturn the Panel for not following what the Appellate Body called its prior interpretations. Yet, in our view, the Panel had the more cogent argument.

After holding that the FIT could potentially be a direct transfer of funds, the Appellate Body failed to provide any reason why the FIT was not so. ${ }^{86}$ Japan had argued before the Panel and on appeal that the FIT's financial contribution was not as a purchase of a good, but rather as a direct transfer of funds. The Appellate Body rejected Japan's appeal, finding that the FIT was instead a governmental purchase, but then the Appellate Body rejected Japan's argument that there was a direct transfer of funds on the grounds that Japan had not established that the FIT 'should in addition be characterized as' a direct transfer of funds. ${ }^{87}$ In other words, even though Japan was arguing that the FIT was not a purchase of goods, the Appellate Body faulted Japan for not explaining why the FIT was more than a purchase of goods. Looking at these judicial decisions from the perspective of legal realism, one might assume that neither the Panel nor the Appellate Body wanted to call the FIT a direct transfer of funds.

\subsection{Governments, markets, and government markets}

Another development in the case law is the Appellate Body's turn toward dirigisme. In previous cases, the Appellate Body emphasized the primacy of the market as a key point of reference in disputes about regulations, technical standards, and subsidies. Yet, in this dispute, the Appellate Body emphasizes the primacy of government volitions. In particular, the Appellate Body first shields government dictates on technology from being considered a subsidy, and then subordinates realworld market outcomes to the markets that a government would prefer exist when the government is, in effect, putting its money (or the taxpayers' money) where its mouth is by using government procurement to reshape demand.

Whereas in previous case law, the market was a separate realm from the government, here the Appellate Body at times seems to see the market merely as interrelated with the government. To wit, 'Where a government creates a market, it cannot be said that the government intervention distorts the market, as there would not be a market if the government had not created it.' 88 To be sure, electricity markets are unusual in being characterized by a mix of competitive supply, natural monopolies, public infrastructure, and needed environmental regulation.

Still, this holding begs the question of what defines a government-created market. Many market-based environmental regulations actually create a market, in the

85 Panel Report, Canada-Renewable Energy/Canada-Feed-In Tariff Program, para. 7.246.

86 Appellate Body Report, Canada-Renewable Energy/Canada-Feed-In Tariff Program, para. 5.131. 87 Ibid., para. 5.131.

88 Ibid., para. 5.188 . 
form of tradable emission allowances, green certificates, or fuel economy credits. Or is the market that for the preferred technologies, advantaged by the regulation? Or is it a market otherwise characterized by natural monopolies that require regulation to enhance competition? Or is it any market for a new technology or product that cannot compete on its own? Furthermore, can it not be recognized that markets can be created in more or less-efficient ways, and that distortions associated with government intervention are equally possible? The complex markets for electricity offer examples of all these issues, but so do some markets more related to industrial policy than energy policy.

Before the Renewable Energy case, the conventional wisdom was that Ontario's FIT program (like many FIT programs) purchases electricity at above-market prices (see Griffin (2013: 217). The Appellate Body, in effect, moved the goalpost by redefining the market to be electricity from renewable sources. As a result, the question of whether the prices paid in the FITs are above market prices no longer has an obvious answer.

In not taking the path pointed to by the dissenting Panelist, the Appellate Body continues its practice of delegating to itself decisions that are politically sensitive. The dissenter would have found a benefit by the mere fact that the investors in renewable generation capacity were getting a deal that they would not have got from the market. The Appellate Body's approach is more textured, but also more government-centric, ${ }^{89}$ in hypothesizing a government-inspired renewable electricity market and then seeing if the FIT contract payments set by the government are too generous relative to that benchmark.

Perhaps the most extensive criticism of the Appellate Body's analytical approach was that authored by Luca Rubini (2014), who faults what he calls an unprecedented antitrust-type analysis examining supply and demand factors. While we agree with a lot of his criticism, we differ from him in not absolutely rejecting the selection of a renewable energy electricity market as the relevant market for determining whether a benefit exists. Instead, our concern is the lack of cogency in the Appellate Body's holding that the so-called supply factors outweigh the demand factors. 90 The Appellate Body does not explain how to compare the relative weights of the supply and demand factors, and we do not see how to carry forward its analysis into a new case. The Appellate Body's analysis boils down to the argument that when the government defines the energy supply mix, such regulation itself creates 'competitive markets' for wind- and solar-produced electricity that should be the focus for a determination of whether a benefit exists from a FIT. ${ }^{91}$ But in our view, it is disturbing to think that whatever government policies emerge from public choice, distortions are automatically mapped into

89 Often when the Appellate Body says 'market-based', it seems to mean government-centric. Ibid., para. 5.225 .

90 Ibid., para. 5.178.

91 Ibid. 
the baseline in determining whether a recipient of a financial contribution is better off than it would have been in the marketplace. Besides preferences about diversification in electrical generation, governments may have preferences about the need for state-owned enterprises, the benefits of technological localization, the value of export-led manufacturing, the recalibrating of transatlantic income tax symmetry, or the rebalancing of income levels in the world economy. Nor does the ruling seem to restrict itself to the arguably unique case of electricity markets.

The Appellate Body does not seem to recognize the slippery slope it has created by introducing policy considerations into the determination of benefit (in seeming contradiction to its own case law) and by equating politician preferences with consumer preferences. ${ }^{92}$ Perhaps the Appellate Body should have given more attention to the dissenting jurist's warning that the fact that a market does not meet the objectives that a government might have does not shield financial contributions from benefit analysis. ${ }^{93}$

The Appellate Body's decision has been the subject of considerable criticism. In the DSB debate surrounding the adoption of the reports, the US government expressed concerns about the Appellate Body's approach, stating that it was not clear how the new definition of the relevant market 'would continue to maintain the SCM Agreement disciplines on a wide range of potential subsidies' (WTO, 2013: para. 8.7). The Appellate Body's decision has also been criticized by trade law commentators. For example, Aaron Cosbey and Petros C. Mavroidis warn that the ruling 'seems to have opened the door wide to infant industry protection' and to 'industrial policy unlimited' $(2014: 26,28)$ Rajib Pal warns that the decision 'permits WTO Members to parse an existing product market into separate markets defined according to production technology, and provide support to chosen higher cost producers ... without fear of repercussions under the SCM Agreement,' and that it 'potentially removes a wide range of trade-distorting government support programs from the scope of the SCM Agreement' (2014: 135-36). Rubini argues that the vagueness of the Appellate Body's language opens the door for 'dangerous analogic reasoning in cases to come, and not necessarily in the clean energy sector only' (2014: 914).

Moreover, we are not convinced of the salience of the distinction suggested by the Appellate Body between 'government interventions that create markets that would otherwise not exist and, on the other hand, other types of government interventions in support of certain players in markets that already exist or to correct distortions therein'. ${ }^{94}$ The Appellate Body seems to suggest a different evaluation for government support for new players than from interventions

92 For example, see ibid., para. 5.177. Of course, the Appellate Body claims that it cannot introduce legitimate policy considerations into the determination of benefit. Ibid., para. 5.185.

93 Panel Report, Canada-Renewable Energy/Canada-Feed-in Tariff Program, para. 9.6.

94 Appellate Body Report, Canada-Renewable Energy/Canada-Feed-In Tariff Program, para. 5.188. 
that affect incumbents, even though both might be aimed at correcting a market failure (or creating one). More generally, the Appellate Body seems to overlook the significance of government interventions that create as many distortions as they attempt to resolve - for example, price controls in markets lead to underinvestment, requiring other interventions to create a market for new capacity.

As noted above, the Appellate Body failed to justify its holding that a government's 'definition' of its desired 'supply mix' of sources of energy to generate electricity does not itself confer a benefit, albeit a potentially rational one. The Appellate Body did not justify this statement, so we can try to do so. The Appellate Body suggested that a supply mix could be implemented through government purchases or a requirement that the private sector purchase the preferred electricity mix. Implementation through government purchases can be a financial contribution; whether it is a benefit depends on the (over)adequacy of remuneration. Implementation through a government mandate is presumably not a financial contribution unless the private body is carrying out a government function. So a requirement that utilities purchase renewable electricity at a premium would not be a financial contribution.

Now go back to the choice of supply mix. Consider, for example, a choice for doubling the use of solar power. Why is that not a benefit to the solar producers? Surely they are better off than they would be in the solar panel market without the government intervention. Perhaps what the Appellate Body is suggesting is that under SCM Article 1, benefits do not exist in the abstract; there can only be a benefit linked to a financial contribution. So notwithstanding its practical beneficial effect on solar producers, government regulatory action to double the use of solar energy is not itself a subsidy because there is no financial contribution from the regulation, and concerted government procurement, while a financial contribution, does not constitute a benefit per se. That interpretation could bode well for many of the equivalent renewable support schemes implemented through decentralized mechanisms, but it could also open the door to less desired interventions.

Since the expiration of Article 8 of the SCM Agreement (Non-Actionable Subsidies), explicit policy considerations have been absent from the SCM Agreement. So while we agree with what the Appellate Body said about not taking into account policy considerations in the determination of benefit, ${ }^{95}$ in contrast to what the Appellate Body did to infuse policy considerations into the ascertainment of a benefit, we do believe that the SCM law might be better if the agreement did take into account policy considerations. For example, we would support making certain renewable energy subsidies non-actionable. Whether the existence of a benefit should take into account policy considerations is a more 
difficult question. In good domestic policy, a government might calibrate the benefits of a subsidy to a recipient with the benefits to the public. But at the international level, it is hard for an international judge to determine whether the benefits to Canada (or to the world) justify the benefits to subsidy recipients.

Finally, in pointing to the use of competitive bidding, ${ }^{96}$ the Appellate Body seems to be suggesting a method for governments to use in setting FIT prices that could show that the price is limited to adequate remuneration. By avoiding the creation of a benefit, a government could insulate its environmental subvention from the rules of the SCM Agreement, particularly the rules on non-discriminatory domestic subsidies that have adverse effects. Commenting on another WTO subsidy case, Neven and Sykes have noted that when there is competitive bidding, 'there is good reason to believe that competition for the contract will reduce the rent accruing to the winner' (2014: 289).

\subsection{Notifying subsidies}

The SCM Agreement requires governments to notify the WTO of specific subsidies. ${ }^{97}$ This is an important provision in achieving trade transparency, but its effectiveness could be weakened if governments gained a new avenue for denying that their aid programs are in fact subsidies. The Renewable Energy decision, by making a finding of 'benefit' less predictable, could undermine the norm of notification. Several WTO scholars, such as Rubini (2014: 918) and Casier et al. (2014: 611), have called attention to this potential fallout from the Appellate Body's decision.

\subsection{Greenwashing}

Finally, perhaps showing how the ghost of the Tuna-Dolphin reports still haunt the WTO, the Appellate Body seemed to go out of its way to express its environmental bona fides. How else could one interpret the Appellate Body's holding that 'fossil fuel resources are exhaustible, and thus fossil energy needs to be replaced progressively if electricity supply is to be guaranteed in the long term'. ${ }^{98}$ In our view, such a holding is hardly justified by the norms of trade law. Indeed, this particular statement is not persuasive on environmental grounds, as it seems to imply that the most compelling reason to replace conventional energy with renewable energy is that the planet is running low on conventional energy, not that it is facing the challenge of climate change.

However, the language in this statement does hearken directly to the phrasing of the Article $\mathrm{XX}(\mathrm{g})$ exception in the GATT. In that sense, it may serve as a subtle reminder of the need for consistency in the GATT and SCM disciplines.

98 Appellate Body Report, Canada-Renewable Energy/Canada-Feed-In Tariff Program, para. 5.186. 


\section{Conclusion}

Canada-Renewable Energy presented a challenging case in which preferential payments for electricity generation were being used to incentivize capacity investment in renewable energy, seeking to modify the generation mix in a historically regulated market. At the same time, a local content requirement was used to earmark the preferential treatment toward installing locally manufactured equipment. The Panel and Appellate Body were rightly in agreement that the LCR constitutes a WTO violation but demurred as to whether a FIT constitutes a subsidy. The greater, unspoken question is whether WTO law poses obstacles for socially merited environmental policies, and the dispute process largely avoided this confrontation.

However, by avoiding the determination of whether an environmentally minded program confers a benefit under the SCM, the Appellate Body may have opened the door for any number of well or poorly intentioned interventions. Cosbey and Mavroidis make this point forcefully, noting the incongruity of the Appellate Body's 'acrobatic' analysis in trying to avoid finding the FIT a subsidy (2014: $32 \mathrm{n}$. 24). The irony is that this broadening of benefit analysis, and all the machinations regarding the relevant benchmarks in the electricity market, comes from a dispute that was fundamentally not about electricity trade, as the complainants have no electricity trade with Canada. Rather, the dispute was about eliminating non-tariff barriers to imported renewable energy generation equipment.

In fact, were the FIT found to be an electricity subsidy, it would be difficult to find a partner in electricity trade harmed by it and willing to challenge it. ${ }^{99}$ Meanwhile, one can also think of other policy designs that would have economically equivalent effects for the generation portfolio-namely, subsidies for renewable energy equipment and installation-and these would not trigger such an analysis of the electricity market, as the relevant market would be that of the manufactured equipment. Furthermore, in this situation, the subsidy would be viewed as a consumption subsidy, if also available to imports, rather than a production subsidy, and again a finding of harm would be challenging to identify.

Thus, had the Appellate Body found that the FIT were a subsidy, it is far from clear that this would have caused irreparable damage to renewable energy policy-making. Still, that judgment might have led to a useful conversation about aligning the SCM with internationally agreed-upon sustainable development goals. Instead, the Appellate Body, like the Panel, seems to have tried to shield the WTO from broad criticisms from the environmental community. In our

99 In this case, the United States is the only trade partner, and several of its states rely on FITs themselves. 
view, the environmental community would be more comfortable with a new discussion of including reasonable environmental exceptions in the SCM Agreement than with having to rely on judicial creativity on an ongoing basis.

\section{References}

Auditor General of Ontario (2011), 'Electricity Sector - Renewable Energy Initiatives', 2011 Annual Report of the Auditor General of Ontario, Chapter 3, Section 3.03.

Buen, J. (2006), 'Danish and Norwegian Wind Industry: The Relationship between Policy Instruments, Innovation and Diffusion', Energy Policy, 34(18): 3887-3897.

Casier, L., R. Fraser, M. Halle, and R. Wolfe (2014), 'Shining a Light on Fossil Fuel Subsidies at the WTO: How NGOs Can Contribute to WTO Notification and Surveillance', World Trade Review, 13(4): 603-632.

Charnovitz, S. (2002), 'The Law of Environmental "PPMs" in the WTO: Debunking the Myth of Illegality', Yale Journal of International Law, 27(1): 59-110.

Cosbey, A. and P. C. Mavroidis (2014), 'A Turquoise Mess: Green Subsidies, Blue Industrial Policy and Renewable Energy: The Case for Redrafting the Subsidies Agreement of the WTO', Journal of International Economic Law, 17: 11-47.

Couture, T. D., K. Cory, C. Kreycik, and E. Williams (2010), A Policymaker's Guide to Feed-In Tariff Policy Design, Technical Report NREL/TP-6A2-44849 (July 2010), Washington, DC: National Renewable Energy Laboratory.

Energy Information Administration (EIA) (2014), 'Electricity Trade', Annual Energy Outlook 2014, Washington, DC: EIA, Table A10.

EU (European Union) (2009a), Climate Action. Europa: Gateway to the European Union, http://ec.europa. eu/environment/climat/climate_action.htm (accessed 5 March 2010). (2009b), Directive 2009/28/EC of the European Parliament and of the Council of 23 April 2009 on the Promotion of the Use of Energy from Renewable Sources and Amending and Subsequently Repealing Directives 2001/77/EC and 2003/30/EC, http://eurlex.europa.eu/LexUriServ/ LexUriServ.do?uri=OJ:L:2009:140:0016:0062:EN:PDF (accessed 5 March 2010).

Fischer, C. (2010), 'When Do Renewable Portfolio Standards Lower Electricity Prices?', The Energy Journal, 31(1): 101-120.

Fischer, C., M. Greaker, and K. E. Rosendahl (2014), Robust Policies against Emission Leakage: The Case for Upstream Subsidies, CESifo Working Paper Series No. 4742.

Fischer, C. and R. G. Newell (2008), 'Environmental and Technology Policies for Climate Mitigation', Journal of Environmental Economics and Management, 55(2): 142-162.

Fischer, C., R. Newell, and L. Preonas (2013), Environmental and Technology Policy Options in the Electricity Sector: Interactions and Outcomes, Discussion Paper 13-20, Washington, DC: Resources for the Future.

Fischer, C. and L. Preonas (2010), 'Combining Policies for Renewable Energy: Is the Whole Less Than the Sum of Its Parts?', International Review of Energy and Resource Economics, 4(1): 51-92.

Fischer, C. and S. Salant (2014), Limits to Limiting Emissions: Spatial Leakage, Intertemporal Leakage, and Negative Leakage, Working Paper, Washington, DC: Resources for the Future.

Flood, B. (2014), ‘US Brings WTO Case against Indian Solar Program', Bloomberg BNA Daily Report for Executives, 28 May 2014.

Griffin, S. (2013), 'The World Trade Organization: A Barrier to Green Energy', Transnational Law and Contemporary Problems, 22: 205-226.

Hestermeyer, H. P. and L. Nielsen (2014), 'The Legality of Local Content Measures under WTO Law', Journal of World Trade, 48: 553-591.

Huberty, M., H. Gao, J. Mandell, and J. Zysman (2011), Shaping the Green Growth Economy: A Review of the Public Debate and the Prospects for Green Growth, Preliminary version (31 March 2011), Berkeley, CA: Berkeley Roundtable on the International Economy. 
International Energy Agency (IEA) (2013), $\mathrm{CO}_{2}$ Emissions from Fuel Combustion: Highlights, Paris: IEA. Kammen, D. M., K. Kapadia, and M. Fripp (2004), Putting Renewables to Work: How Many Jobs Can the Clean Energy Industry Generate? RAEL Report, Berkeley, CA: University of California.

Lecuyer, O. and C. Fischer (2014), Can a Tariff for Renewable Energy Financed by a Consumer Tax Reduce Electricity Prices? Analysing Interactions with an Emission Cap, Working Paper, Bern, Switzerland: University of Bern.

Ministry of Energy (2010), Ontario Delivers $\$ 7$ Billion Green Investment, http://news.ontario.ca/mei/en/ 2010/01/backgrounder-20100121.html (accessed 31 August 2014).

Nath, I. (2010), 'Cleaning Up after Clean Energy: Hazardous Waste in the Solar Industry', Stanford Journal of International Relations, 11(2): 6-15.

Navigant Consulting (2012), Sector Profile for Solar Photovoltaics in Canada, Report 2012-063 (RP-TEC), CanmetENERGY, Natural Resources Canada, March 2012, http://www.nrcan.gc.ca/ sites/.ca/files/canmetenergy/files/pubs/2012-063-eng.pdf (accessed 31 August 2014).

Neven, D. and A. Sykes (2014), 'United States - Measures Affecting Trade in Large Civil Aircraft (Second Complaint): Some Comments', World Trade Review, 13: 281-298.

Organisation for Economic Co-operation and Development (OECD) (2011), Joint Working Party on Trade and Environment, Domestic Incentive Measures for Renewable Energy with Possible Trade Implications, COM/TAD/ENV/JWPTE(2011)46, Paris: OECD.

Pal, R. (2014), 'Has the Appellate Body's Decision in Canada - Renewable Energy/Canada - Feed-In Tariff Program Opened the Door for Production Subsidies?', Journal of International Economic Law, 17: $125-137$.

REN21 (Renewable Energy Policy Network for the 21st Century) (2013), Renewables 2013 Global Status Report, Paris: REN21 Secretariat.

Rubini, L. (2014), 'The Good, the Bad, and the Ugly', Journal of World Trade, 48(5): 895-938.

Schmidt, R. C. and R. Marschinski (2009), 'A Model of Technological Breakthrough in the Renewable Energy Sector', Ecological Economics, 69(2): 435-444.

Shadikhodjaev, S. (2013), 'First Judicial Review of Climate Change Subsidy Issues', American Journal of International Law, 107(4): 864-878.

Sharp, B. (2013), 'Blame Solar for Sky-High Ontario Power Bills', Financial Post, 29 October.

Sorrell, S. (2003), 'Who Owns the Carbon? Interactions between the EU Emissions Trading Scheme and the UK Renewables Obligation and Energy Efficiency Commitment', Energy and Environment, 14(5): 677-703.

Sorrell, S., and J. Sijm (2003), 'Carbon Trading in the Policy Mix', Oxford Review of Economic Policy, 19 (3): 420-437.

van Benthem, A., K. Gillingham, and J. Sweeney (2008), 'Learning-by-Doing and the Optimal Solar Policy in California', Energy Journal, 29(3): 131-151.

Whitsitt, E. (2013), 'A Modest Victory at the WTO for Ontario's FIT Program', University of California at Davis Journal of International Law and Policy, 20: 75-103.

World Trade Organization (WTO) (2013), 'Minutes of Meeting Held in the Centre William Rappard on 24 May 2013', WT/DSB/M/332, 31 July 2013.

- (2014), Committee on Subsidies and Countervailing Measures, Replies to Questions Posed by India to the United States, G/SCM/Q2/USA/61, Geneva: WTO. 